\title{
Observations on growth of Flustra foliacea (Bryozoa) from Helgoland waters
}

\author{
N. R. MENON \\ Biologische Anstalt Helgoland (Meeresstation); \\ Helgoland, Federal Republic of Germany
}

KURZFASSUNG: Beobachtungen über das Wachstum von Flustra foliacea (Bryozoa) aus den Gewässern um Helgoland. Die Kolonien des Moostierchens Flustra foliacea treten bei Helgoland in großer Abundanz, und zwar yorwiegend in Wassertiefen von 1-20 $\mathrm{m}$, auf. Das Wachstum der Art zeigt einen exponentiellen Verlaul, wobei in aufeinanderfolgenden Jahren unterschiedliche Wachstumsintensitäten, deren Ursachen jedoch noch unklar sind, verzeichnet worden sind. Quantitative Angaben über den Wachstumsverlauf bei verschiedenen Altersklassen, die einen Bereich von 8 Jahren umfassen, werden mitgeteilt.

\section{INTRODUCTION}

Only limited information is available on the growth rate of members of natural populations of bryozoans. EDMONDSON \& INGRAM (1939) studicd the rate of growth of Bugula neritina and Schizoporella unicornis. According to these authors, S. unicornis grows on average $1 \mathrm{~mm}$ per day in diameter, for the first month, after which growth declines. Mawatari $(1951,1952,1953)$ noted the growth rates of $B$. neritina, Watersipora cucullata and Electra angulata in Japanese waters, and concluded that the growth of Electra angulata is very rapid. SKERMANN $(1958,1959)$ examined the growth rates of Cryptosula pallasiana, B. neritina and $B$. flabellata at the ports of Lyttleton and Auckland and noticed that spring settling colonies of C. pallasiana measured $12 \mathrm{~cm}^{2}$. KAWAHARA (1960) studied the growth, maturation and propagation of B. neritina. MENON \& NAIR (1972) elucidated the growth of four species of bryozoans, Electra crustulenta, E. bengalensis, Alderina arabianensis and Schizoporella cochinensis, and concluded that these bryozoans grow exponentially. STEBBING (1971) found that Flustra foliacea grows in a uniform manner for at least 8 years, and that annual growth checks give reliable information on the yearly growth increment of this perennial bryozoan.

\section{MATERIAL AND METHODS}

Colonies of Flustra foliacea were collected by diving and dredging at depths ranging from 1 to $50 \mathrm{~m}$ from the Helgoland waters (southern North Sea). Aquanauts 
collected the colonies from 1 to $12 \mathrm{~m}$ depths, and a toothed hydroid dredge was employed on board FK "Uthörn" and FK "Heincke" to collect the colonies from 10 to $50 \mathrm{~m}$ depths. Collections at bi-monthly intervals were made from May 1971 to February 1972. The positions of the stations where dredgings were done are $54^{\circ}$ $08^{\prime} 27^{\prime \prime} \mathrm{N}, 07^{\circ} 54^{\prime} 17^{\prime \prime} \mathrm{E} ; 54^{\circ} 08^{\prime} 57^{\prime \prime} \mathrm{N}, 07^{\circ} 52^{\prime} 20^{\prime \prime} \mathrm{E} ; 54^{\circ} 09^{\prime} 03^{\prime \prime} \mathrm{N}, 07^{\circ} 53^{\prime} 06^{\prime \prime} \mathrm{E}$ and $54^{\circ} 07^{\prime} 11^{\prime \prime} \mathrm{N}, 07^{\circ} 51^{\prime} O 2^{\prime \prime}$ E. Flustra foliacea was found in abundance only at depths ranging from 1 to $20 \mathrm{~m}$.

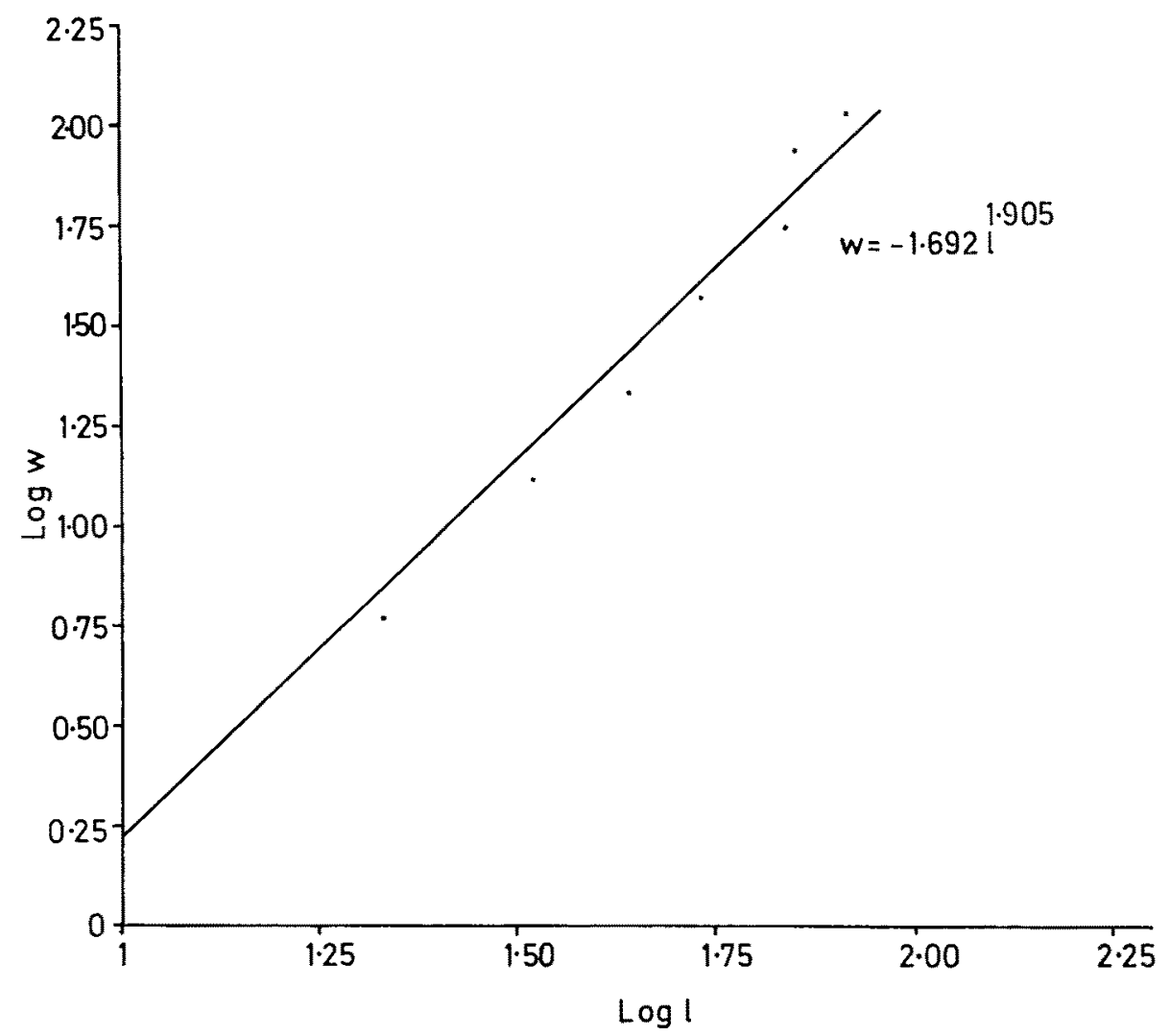

Fig. 1: Growth curve showing the relationship between length $(\log 1)$ and weight $(\log w)$ in Flustra foliacea

The heights of colonies of Flustra foliacea ranging from 2 to 8 years in age were measured. The height attained during the first year of growth was evaluated by the previous growth increments as no colony of this age group could be collected intact. Wherever possible growth data of earlier years for older colonies obtained by this method were also utilised.

After recording the length, the colonies were oven dried at $40^{\circ} \mathrm{C}$ for $24 \mathrm{~h}$. On obtaining constant dry weight of the whole colony, it was cut along the different growth check lines and weighed to find out the increase in weight, during the different 
years of growth. The data recorded were utilised to estimate the rate of growth of Flustra foliacea of Helgoland waters.

\section{RESULTS AND DISCUSSION}

The details regarding length, weight and co-efficient of variations within each age group are presented in Table 1.

The observed data on growth were fitted to the equation $\mathrm{W}=-1.692 \mathrm{I}^{1.905}$. Employing this formula, the expected values for weight $(\log w)$ were calculated against length $(\log 1)$. The results are plotted in Figure 1. The close fitting of the observed and calculated data shows that the formula can be employed to estimate the grow th of any colony from the Flustra foliacea population of Helgoland waters.

Table 1

Data on growth of Flustra foliacea

\begin{tabular}{|c|c|c|c|c|c|c|c|}
\hline \multirow{2}{*}{$\begin{array}{c}\text { Age } \\
\text { group } \\
\text { (yeurs) } \\
1\end{array}$} & \multirow{2}{*}{$\begin{array}{l}\text { No. of } \\
\text { abserva- } \\
\text { cions } \\
64\end{array}$} & \multicolumn{2}{|c|}{$\begin{array}{l}\text { Length (mm): } \\
\text { Arithmetical } \\
\text { means (standard } \\
\text { deviation with- } \\
\text { in parenthesis) }\end{array}$} & \multirow{2}{*}{$\begin{array}{l}\text { Coefficient } \\
\text { of rariation } \\
\frac{24.8}{4}\end{array}$} & \multicolumn{2}{|c|}{$\begin{array}{l}\text { Weight (mg): } \\
\text { Arithmetical } \\
\text { means (standard } \\
\text { deviation with- } \\
\text { in parenthesis) }\end{array}$} & \multirow{2}{*}{$\begin{array}{l}\text { Coefficient } \\
\text { of variation } \\
\frac{110.7}{-}\end{array}$} \\
\hline & & 10.0 & $(2.5)$ & & 2.1 & $(2.3)$ & \\
\hline 3 & 63 & 21.2 & $(4.6)$ & 21.9 & 5.9 & $(3.1)$ & 528 \\
\hline 3 & 61 & 32.0 & $(6.0)$ & 18.8 & 13.2 & $(6.4)$ & 48.4 \\
\hline ! & 47 & 43.6 & $(7.3)$ & 16.8 & 21.6 & (12.3) & 57.0 \\
\hline 5 & 27 & 53.5 & $(1.7)$ & 3.1 & 36.8 & $(13.9)$ & 37.8 \\
\hline 6 & 30 & 60.9 & $(4.6)$ & 7.6 & 55.9 & (11.9) & 67.7 \\
\hline 7 & 27 & 71.1 & $(6.5)$ & 7.7 & 86.9 & $(17.8)$ & 20.5 \\
\hline$\ddot{b}$ & 27 & 79.3 & $(5.4)$ & 6.7 & 109.1 & $(14.4)$ & 13.2 \\
\hline
\end{tabular}

It is clear from STLBBng's (1971) observations that the number of zooid layers increases as a function of age. He has found out that additional layers are added on, at a constant rate, as the colonies grow in height. Notwithstanding the increase in zooid layers the real functioning zooids of the colony are present on the surface of the colony only. Hence increase in weight should give a more reliable information. $\Lambda$ though the pattern of growth is exponential, the rate of growth of colonies was not uniform during different years. This is obvious, as the growth of the colonies is controlled by various physical, chemical and biological factors, which invariably show seasonal and yearly fluctuations. It has been shown that the physical and chemical parameters and the periods of abundance in phytoplankton of Helgoland waters vary from year to year (e. g. HAGMEIER et al., 1974).

Although we have no documented evidence on the type of food of these bryozcans, it can safely be assumed that they are phytoplankton feeders. The size of the food organism may be important, as this seems to be mainly influenced by the size of the lophophore. Hence a uniform growth cannot be expected as the above factors affect life and activity of these sedentary organism. From the present data, it is clear 
that, as the colonies grow older, the pace of growth decreases and intra-colonial variations in growth rates also occur (Table 1). The five-year group of colonies showed little annual variation in growth in height (coefficient of variation being only 3.1). However, the coefficient of variation data shows that this was also less in the $7-$ and 8 -year class.

STEBBING (1971) has pointed out that growth of epizoites on the colonies can result in retardation of vegetative growth. The intensity of settlement of epizoites was uniformly meagre and only Crisia eburnea formed a major bryozoan epizoite which, being a dendrite form, did not occupy the surface area of the colonies. Observations on the growth of colonies of three anascous bryozoans under natural conditions indicated that no retardation of growth occurs during the early phase (MENON \& NaIR, 1972). From the available literature it becomes clear that the growth of Flustra foliacea is comparatively rapid compared to other anascous bryozoans. This may be due to the foliaceous nature of the colony and multilaminar arrangement of zooids in this species.

\section{SUMMARY}

1. The growth rates of Flustra foliacea has been estimated for 8 years by evaluation of previous growth increments.

2. The growth of the colonies was found to be exponential.

3. Intra-annual variation in growth was noticed. This was very conspicuous between the 5-year and 6-year class.

4. The equation $W=-1.69211 .905$ can be employed to assess the growth rate of this species in Helgoland waters.

5. The intensity of settlement of epizoites was less when compared with other localities in the North Sea.

Acknowledgements. I am deeply indebted to Professor Dr. O. KINNE, Leading Director and Professor of the Biologische Anstalt Helgoland, for his help and encouragement and his personal interest during my stay on Helgoland. Thanks are due to $\mathrm{Mr}$. T. Hornsmann, Mr. J. STOLDT and the crew of FK "Heincke" and FK "Uthörn" for their wholehearted help and assistance at sea. The services rendered by Mr. Posse and Mr. Schomburg are gratefully acknowledged. Help rendered by Mrs. J. MENON in the laboratory and Mr. K. S. UDuPA, College of Fisheries, Mangalore for the statistical analyses of the data are adknowledged.

\section{LITERATURE CITED}

Edmondson, C. H. \& Ingram, W. H., 1939. Fouling organism in Hawaii. Occ. Pap. Bernice P. Bishop Mus. 14, 251-300.

Hagmeier, E., Kanje, M. \& Treutner, K., 1974. Hydrographie, Chemie und Sestongehalt des Wassers bei Helgoland. Jber. Biol. Anst. Helgoland 1973, 24-28.

KAwahara, T., 1960. Analysis of ecological phenomena in the community of sessile organism (1). Extinction of Bugula neritina LinNé and Stylea plicata (Linnaeus) from the community. Rep. Fac. Fish. Prefect. Univ. Mic. 3, 565-572. 
MawataRI, S., 1951. The natural history of a common fouling bryozoan Bugula neritina (Linnaeus). Misc. Rep. Res. Inst. nat. Resour. Tokyo 8, 9-16.

- 1952. On Watersipora cucullata (Busk). II. Misc. Rep. Res. Inst. nat. Resour. Tokyo 28, $17-21$.

- 1953. On Electra angulata Levinsen one of the fouling bryozoans in Japan. Misc. Rep. Res. Inst. nat. Resour. Tokyo 32, 5-10.

Menon, N. R. \& NatR, N. B., 1972. The growth rates of four species of intertidal bryozoans in Cochin backwaters. Proc. Indian Natl. Sci. Acad, 38 (B), 397-402.

SKERMAN, T. M., 1958. Marine fouling at the port of Lyttelton. N. Z. J1 Sci. 1, 224-257.

- 1959. Marine fouling at the port of Auckland. N. Z. Jl Sci. 2, 57-94.

Sterbing, A. R. D., 1971. Growth of Flustra foliacea (Bryozoa). Mar. Biol. 9, 267-273.

Author's address: Dr. N. R. Menon

College of Fisheries

Mangalore 575002

India 